\title{
Formulation and evaluation of topical halofuginone gel using a novel ex vivo model
}

\author{
Awatef Sassi ${ }^{1,2 \star}$, Balcem Kacem ${ }^{3}$, Amel Hassairi ${ }^{1}$, Mehdi Jaidane ${ }^{1}$, Saad \\ Saguem ${ }^{1}$ \\ ${ }^{1}$ Metabolic Laboratory of Biophysics and Applied Occupational and Environmental Toxicology, Faculty of Medicine, University \\ of Sousse, ${ }^{2}$ Faculty of Science of Bizerte, Zarzouna, ${ }^{3}$ Chemical, Pharmacological and Pharmaceutical Drug Development, \\ Faculty of Pharmacy, Monastir, Tunisia
}

*For correspondence: Email: awatefsassi@yahoo.com; Tel: +216992882691

Sent for review: 7 November 2017

Revised accepted: 20 April 2018

\begin{abstract}
Purpose: To formulate and study the kinetics of delivery and retention of three halofuginone (HF) gels via different wall layers of an ex vivo model mimicking urethral tissue.

Methods: Three HF hydrogels ( $a, b$ and $c)$ of the same concentration $(0.03 \% \mathrm{w} / \mathrm{v})$ incorporating different levels of sodium carboxymethyl cellulose (Na-CMC), were prepared. The viscosity of the different gels was studied at $37^{\circ} \mathrm{C}$ and at room temperature. The release of HF from these hydrogels and its diffusion into urethral tissue were evaluated using a new ex vivo model mimicking human urethral tissue. The amount of HF was determined by HPLC method.

Results: The release of HF increased with increasing viscosity and duration of contact. Gel c showed the best drug release after $2 \mathrm{~h}$ of diffusion, with $65.7 \% \mathrm{HF}$ in the wall of the ureter. The model showed a uniform distribution of the drug throughout the ureter tissue. In comparison, HF was not detected in the receiver compartment until $2 \mathrm{~h}$.

Conclusion: Topical HF gel application is a suitable solution for the potential treatment of urethral stricture and/or recurrence. The formulation and characterization of the ureter model should facilitate the development of new therapeutics for urethral diseases.
\end{abstract}

Keywords: Halofuginone gel, Urethra, Wall diffusion, Urethral stenosis

\begin{abstract}
This is an Open Access article that uses a funding model which does not charge readers or their institutions for access and distributed under the terms of the Creative Commons Attribution License (http://creativecommons.org/licenses/by/4.0) and the Budapest Open Access Initiative (http://www.budapestopenaccessinitiative.org/read), which permit unrestricted use, distribution, and reproduction in any medium, provided the original work is properly credited.
\end{abstract}

Tropical Journal of Pharmaceutical Research is indexed by Science Citation Index (SciSearch), Scopus, International Pharmaceutical Abstract, Chemical Abstracts, Embase, Index Copernicus, EBSCO, African Index Medicus, JournalSeek, Journal Citation Reports/Science Edition, Directory of Open Access Journals (DOAJ), African Journal Online, Bioline International, Open-J-Gate and Pharmacy Abstracts

\section{INTRODUCTION}

The development of urethral stricture is a fibrotic process. It is associated with the deposition of non-compliant scar tissue in the spongy zone surrounding the urethra, and it leads to a decrease in luminal diameter [1]. The spongy tissue surrounds the strictured urethra and modifies the collagen content. Therefore, there is an unusually high proportion of type 1 collagen, relative to type 3 which usually dominates in a scar [2]. These strictures are usually due to chronic or recurrent infection, instrumentation, catheterization, external trauma and urethritis [3]. They result in blocked micturition in young men, as well as frequent recurrence after the initial treatment. When a stricture occurs, the patients need frequent hospitalization, which entails 
increased cost of healthcare in addition to a decrease in life quality [4]. Conventional and effective treatment strategies for urethral strictures include visual internal urethrotomy and urethral dilation. However, recurrence occurs in many patients just because no treatments can prevent these relapses [1].

Halofuginone resembles febrifugine, an alkaloid originally isolated from Dichroa febrifuga, which is a potent inhibitor of collagen a 1 type 1 gene expression and extracellular matrix deposition [5]. So far, no other specific inhibitor of collagen type 1 synthesis is known apart from HF [6-8]. This inhibition is usually studied in cell cultures and in animal models of fibrosis in which abnormal collagen deposition takes place $[8,9]$. It reduces fibrosis and adhesion formation in many human tissues [6,7]. Relying on its mode of action, HF is used to prevent and treat various diseases caused by excessive type 1 of collagen synthesis such as scleroderma [8], liver cirrhosis [10], adhesion after abdominal surgery [11], esophageal stricture [12] and burn scar [9].

Animal studies have demonstrated that $\mathrm{HF}$ is a promising treatment for limiting urethral stricture formation and recurrence [13]. The present study was carried out to develop effective treatment of urethral stricture in humans. Due to the effectiveness of local application of HF in dermal disease, and difficulties associated with oral therapy in humans, endo-urethral topical gel was used. The gel was based on NaCMC a non-toxic natural polysaccharide, so as to ensure sufficient contact time with the urethra wall [14].

The histological resemblance between the urethra tissue and human ureter wall was exploited in studying diffusion of HF by using the ureter as an ex vivo model to simulate the urethra.

The study was designed to obtain and evaluate a gel formulation permitting optimal retention of $\mathrm{HF}$ in the wall of the human ureter using a novel model mimicking human urethra.

\section{EXERIMENTAL}

\section{Chemicals}

Standard HF hydrobromide and carboxymethyl cellulose were products of Discovery of Fine Chemicals, Dorset, and Prolabo, Paris, respectively. Other chemicals and their sources included imipramine HCL (Sigma Ultra (England), HPLC-grade acetonitrile and propane-2-ol (Lab Scan); ammonium acetate, sodium carbonate and trypsin (Sigma Aldrich); acetic acid (Merck), and triethylamine (Fluka). Others were ammonium sulfate (Riedel-de Haên), and phosphate buffered saline (Prolabo, Paris).Purified water was produced using Millipore (Arium 611DI/611UV) equipment in our laboratory. All the othersc hemicals used were of analytical grade.

\section{Human ureter tissue}

Human ureter was got fresh during kidney transplantation at Sahloul Hospital, Sousse, Tunisia. The ureter is usually available in the kidney transplanting departments because the donor's kidney is always removed through a long ureter with some portions trimmed off according to the receiver anatomy. These portions may be retrieved after obtaining the donor's consent, and preserved in Eurocollins ${ }^{\circledR}$ solution. The Research Ethics Committee of Sahloul University Hospital of Tunisia approved gave ethical approval for the use of the ureter as an ex vivo model (ref no. 13218). The guidelines followed were in accordance with the principles set in Declaration of Helsinki [15].

The ureter was divested of surrounding excess adipose tissue. Depending on the experience, the ureter was opened to a rectangular shape to enable the study of diffusion kinetics, or maintained intact for performing endourethral instillation. All samples were immersed in physiological saline to eliminate traces of preservation fluid, and dried with Whatman filter paper no. 1.

\section{Ureter model used}

Due to the histological resemblance between the human urethra and ureter wall, the latter was used as an ex vivo model to simulate human urethra in the study of the diffusion of HF. Thus, the living human ureter was used to predict the diffusion of HF through the urethra wall and its three-dimensional distribution in this tissue. The study was conducted in two parts. The first part investigated passive diffusion of the drug into the tissue and the absence of passage in the recipient compartment. It consisted of evaluating the release of HF from the gel, and its retention in the ureter tissue using a diffusion cell. The second part studied the three-dimensional homogeneous diffusion of HF through the tubular shape of the human ureter.

\section{Preparation of HF hydrogels.}

Three different gels $a, b$ and $c$ were prepared by varying the concentrations of $\mathrm{Na}-\mathrm{CMC}$ at fixed concentration of $\mathrm{HF}$ (Table 1). The $\mathrm{pH}$ of the 
three gels ranged between 7 and 7,5. The hydrogels were packed into glass tubes securely closed and stored at $4^{\circ} \mathrm{C}$ prior to use.

Table 1: Composition of HF hydrogel

\begin{tabular}{|c|c|c|c|}
\hline $\begin{array}{l}\text { Component }(\% \\
w / v)\end{array}$ & Gel a & Gel b & Gel c \\
\hline HF (\%) & 0.03 & 0.03 & 0.03 \\
\hline $\mathrm{NaCMC}(\%)$ & & & \\
\hline Distilled water & $Q s^{*}$ & Qs & Qs \\
\hline
\end{tabular}

\section{Viscosity measurement}

For each of the gels, viz, a, b, and c, three measurements of viscosity were made at $37{ }^{\circ} \mathrm{C}$ and at room temperature, using a field brook field DV-III with spindle LV61. The impact of gel viscosity on tissue diffusion was then studied.

\section{Ex vivo permeability studies}

The studies were performed using a modified diffusion cell (exposed area: $50 \mathrm{~mm}^{2}$ ). The ureter samples were subsequently sandwiched between the receiver and donor compartments of the diffusion cell, with the inner part of ureter opposite the donor chamber, while the outer part side is faced the receptor chamber. Phosphate buffer saline (PBS) pH 7.4 was used as a receptor media and the cell contents were maintained at a temperature of $37 \pm 1{ }^{\circ} \mathrm{C}$, with constant stirring at $100 \mathrm{rpm}$ on a small magnetic bar. The donor compartment was then filled with $300 \mathrm{mg}$ of gel containing HF at $0.03 \%(\mathrm{w} / \mathrm{v})$. The receptor interface was blocked with parafilm to ensure that the gel did not evaporate. To the receiver chamber was added $2.5 \mathrm{ml}$ of PBS at 30-min intervals up to $120 \mathrm{~min}$. Aliquots of $100 \mu \mathrm{l}$ were periodically sampled from the receptor compartment and replaced with an equal volume of buffer. The HF contents of the various samples of PBS were measured by HPLC using an injection volume of $5 \mu \mathrm{l}$ of receiver compartment solution.

\section{Ureter retention studies}

During the 120 min study period, the exposed areas were removed from diffusion cell at timed intervals, and fragments of ureter were rinsed in physiological saline to remove excess drug. The amount of drug retained in each ureter section was measured by HPLC after a step of a liquidliquid extraction using isopropanol [16].

\section{Three dimensional distribution of HF}

Fresh ureter was cut into tubular portions of $3 \mathrm{~cm}$ in length. The HF gel was placed inside each portion of the ureter which was then hermetically sealed at its two ends with sutures. Each portion was placed in a test tube containing PBS at 37 ${ }^{\circ} \mathrm{C}$. The wall of the ureter simulated the four layers of the urethra while the PBS solution simulated the spongy body. After $2 \mathrm{~h}$, the ureters were recovered. Excess gel was removed by rinsing in physiological saline, and the ureters were cut horizontally in two portions. Then vertical cuts resulted in 8 portions of area 37 $\mathrm{mm}^{2}$. The distribution of HF in the ureter wall portions, as well as the amount of HF diffused in the PBS solution, were determined by HPLC.

\section{Chromatographic studies}

The amounts of HF in the human ureter and in the receptor compartment of the cell diffusion in the test tube were determined by HPLC [16]. Theanalysis was carried out in an Agilent 1200 HPLC equipped with G1322A degassers, G1311A quaternary pump, G1315D diode array detector, at an injection volume of $5 \mu \mathrm{l}$. The HPLC was carried out at $30^{\circ} \mathrm{C}$ in a Lichrospher ${ }^{\circledR}$ $\mathrm{C} 18,250 \times 4 \mathrm{~mm}, 5-\mu \mathrm{m}$ column of $4 \mathrm{~mm}$ internal diameter and $250 \mathrm{~mm}$ long; and Lichrospher ${ }^{\circledR}$ 100RP18 guard column $(4 \times 4 \mathrm{~mm})$ with $5 \mu \mathrm{m}$ particle size.

Both HF and internal standard (imipramine) were eluted in gradient mode, and HF was at $243 \mathrm{~nm}$. The HPLC method was successfully validated by applying the novel validation protocol using the accuracy profile based on a concept of the total error. This method is accurate in the range of 0.2 $-10 \mu \mathrm{g} / \mathrm{ml}[16]$.

\section{Statistical analysis}

Data were analyzed using SPSS software, version 18. A comparative univariate statistical study was conducted to determine the factors that influence HF diffusion through the human urethra, and subsequent comparison of the diffusion through the wall of the urethra in the ex vivo model according to the viscosity and/or the contact time. $P<0.05$ was considered statistically significant.

\section{RESULTS}

\section{Ex vivo permeability}

Permeability studies showed that HF did not diffuse into the receptor compartment of the diffusion cell. This implies that HF was retained in the ureter tissue for $2 \mathrm{~h}$. 


\section{Hydrogel viscosity}

Results obtained from viscosity studies at room temperature and at $37^{\circ} \mathrm{C}$ are shown in Table 2.

Table 2: Viscosity of HF hydrogel formulations

\begin{tabular}{|c|c|c|}
\hline \multicolumn{3}{|c|}{ Gel a } \\
\hline RPM & $\begin{array}{l}\text { Viscosity at room } \\
\text { temperature (cPs) }\end{array}$ & $\begin{array}{l}\text { Viscosity at } \\
37^{\circ} \mathrm{C}\left(c P s^{*}\right)\end{array}$ \\
\hline 0.1 & 899 & 419 \\
\hline 0.1 & 899 & 599.9 \\
\hline 0.1 & 1020 & 620 \\
\hline Mean & 939.3 & 546.3 \\
\hline \multicolumn{3}{|c|}{ Gel b } \\
\hline RPM & $\begin{array}{l}\text { Viscosity at room } \\
\text { temperature }(c P s)\end{array}$ & $\begin{array}{l}\text { Viscosity at } \\
37^{\circ} \mathrm{C}(c P s)\end{array}$ \\
\hline 0.1 & 2600 & 1440 \\
\hline 0.1 & 2400 & 1380 \\
\hline 0.1 & 2939 & 1320 \\
\hline Mean & 2646.3 & 1380 \\
\hline \multicolumn{3}{|c|}{ Gel c } \\
\hline RPM & $\begin{array}{l}\text { Viscosity at room } \\
\text { temperature }(c P s)\end{array}$ & $\begin{array}{l}\text { Viscosity at } \\
37^{\circ} \mathrm{C}(c P s)\end{array}$ \\
\hline 0.1 & 8818 & 4308 \\
\hline 0.1 & 8878 & 4799 \\
\hline 0.1 & 8857 & 3500 \\
\hline Mean & 8851 & 4202 \\
\hline
\end{tabular}

The viscosity of the three gels decreased at 37 ${ }^{\circ} \mathrm{C}$, when compared to their viscosities at room temperature. Viscosities also decreased with decreases in the amount of the gelling agent (Na-CMC). Gel c formula had the most important viscosity at $37^{\circ} \mathrm{C}$ (4202 cPs) and at room temperature $(8851 \mathrm{cPs})$.

\section{Ex vivo retention and release study}

At the end of the exposure time $(0,30,60,90$ and $120 \mathrm{~min}$ ) each fragment of the ureter was ground and the HF was extracted to measure its retained proportion within the tissue. The accumulated quantities of $\mathrm{HF}$ in the wall of the ureter in the three gels are shown in Figure 1.

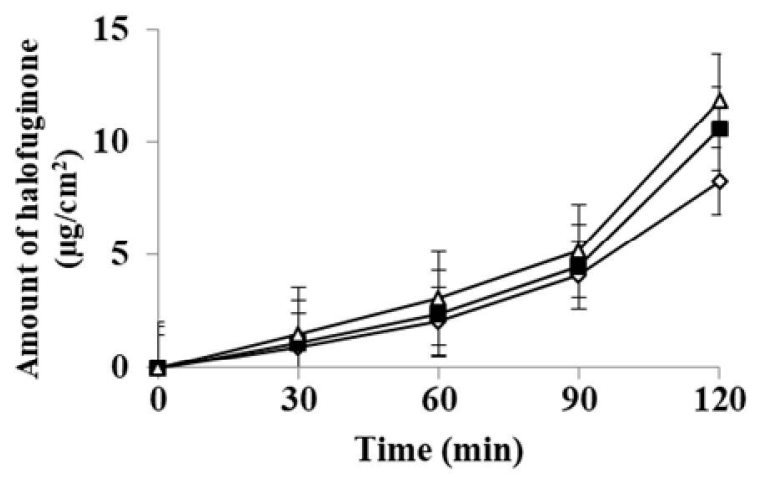

Figure 1: Ex vivo release of $\mathrm{HF}$ through the human wall ureter $(n=5) .(\diamond)=$ Gel a, $(\boldsymbol{\square})=$ Gel b, $(\Delta)=$ Gel c
The curve shows that from the initial applied dose (300 mg/50 $\mathrm{mm}^{2}$ ), the amount of HF diffused into the wall increased during the two hours after application of the gel, to reach $11.83 \mu \mathrm{g} / \mathrm{cm}^{2}$ at $120 \mathrm{~min}$ for gel formula c. On the other hand, diffusion for gel a did not exceed $10 \mu \mathrm{g} / \mathrm{cm}^{2}(8.26$ $\mu \mathrm{g} / \mathrm{cm}^{2}$ ) while that of gel $\mathrm{b}$ barely exceeded 10 $\mu \mathrm{g} / \mathrm{cm}^{2}\left(10.59 \mu \mathrm{g} / \mathrm{cm}^{2}\right)$.

Table 3: HF release from the three hydrogels $(n=5)$

\begin{tabular}{llcc}
\hline $\begin{array}{l}\text { Period } \\
\text { (min) }\end{array}$ & Gel & $\begin{array}{c}\text { Mean HF released (\% } \\
\text { w/v) }\end{array}$ & $\begin{array}{c}\boldsymbol{P} \text { - } \\
\text { value }\end{array}$ \\
\hline \multirow{3}{*}{30} & Gel a & 5.21 & \\
& Gel b & 6.29 & $<10^{-3}$ \\
& Gel c & 8.29 & \\
60 & Gel a & 11.47 & \\
& Gel b & 13.41 & $<10^{-3}$ \\
& Gel c & 17.12 & \\
& Gel a & 22.8 & \\
90 & Gel b & 24.91 & $<10^{-3}$ \\
& Gel c & 28.68 & \\
& Gel a & 45.91 & \\
120 & Gel b & 58.88 & $<10^{-3}$ \\
& Gel c & 65.74 & \\
\hline
\end{tabular}

The amount of HF on the wall of the ureter continued to increase with duration of exposure time, and with viscosity. After two hours, drug permeation was $45.91 \%, 58.88 \%$, and $65.74 \%$ for gels a, b, and c, respectively (Table 3 ). The amounts of HF in the ureter wall after $30 \mathrm{~min}, 60$ $\mathrm{min}, 90 \mathrm{mn}$ and $120 \mathrm{~min}$ increased for the three formulated gels.

A significant association was found between the viscosity and the amount of HF at each period ( $p$ $=10^{-3}$ ). A comparative study of the retention of $\mathrm{HF}$ in the ureter wall as a function of three different gel viscosities for 30,60, 90, $120 \mathrm{~min}$ showed that gel $\mathrm{c}$ which had the highest viscosity gave a higher amount of a drug release, when compared to other two tested gels. Gel c was considered as an optimized gel, and it showed the best kinetics of diffusion.

\section{Three-dimensional distribution of HF}

Gel c was used as the baseline gel in testing the spatial dispersion of the drug in the wall of the human ureter. The results showed that the amount of HF retained in the ureter fragments were almost similar, which is an indication that the drug was uniformly dispersed in the ureter wall after an ex vivo endo-urethral instillation (Figure 2).

The results of analysis revealed that HF was not detected in the receiver compartment of the diffusion cell, and it was also absent in the PBS solution following the investigation of the threedimensional distribution of HF. 


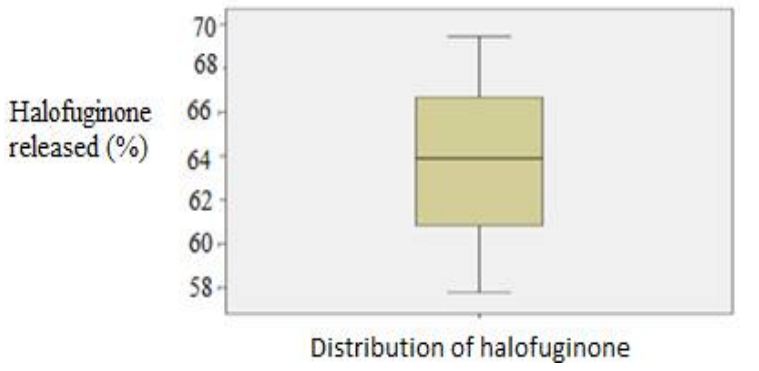

Figure 2: Three-dimensional distribution of halofuginone

\section{DISCUSSION}

This study was aimed at formulating a model hydrogel for delivery of HF, a drug used to treat and to prevent urethra stricture. When instilled, HF was able to penetrate deep into the urethra, and remained there at an effective concentration for $2 \mathrm{~h}$. The kinetics of diffusion is important here, because the patient should be able to refrain from urinating, and in turn eliminating the gel, for a maximum of $2 \mathrm{~h}$. Due to lack of in vitro and in vivo models targeting the human urethra, studies on the urethra were hitherto carried out on animal models such as rabbits $[13,17]$ and rats [18].

The urethral model developed in this study can be useful for researchers involved in the development of potential treatments in urology, andrology, oncology, and sexology. The model is unique and was not described in earlier studies. It will be a valuable and innovative tool for all researchers in the field of urethral and penile pathologies.

The diffusion of drugs in the tissues is influenced by the duration of contact. The longer the duration, the better the diffusion. Diffusion is also influenced by the nature of the gel used. The gel controls the release and diffusion of medications. The nature of the gelling agent and the viscosity of the gels are determining factors in the release of drugs and their diffusion. In the present study, the variation in the amount of $\mathrm{Na}-\mathrm{CMC}$ resulted in variations in gel viscosity. Indeed, the delivery of drugs in gel formulations is influenced by viscosity. Viscosity may directly influence the diffusion of the drug at the microstructure level. The amount of HF diffused in the wall of the ureter depended not only on the duration factor but also on the viscosity of the gel used.

It was noticed that the ex vivo release of the drug progressed with increases in $\mathrm{Na}-\mathrm{CMC}$ content. This was most likely due to the generation of a network of hydrophilic and loose $\mathrm{Na}-\mathrm{CMC}$ cross- links [19]. However, high-viscosity gel formulations may still manifest significant diffusion rates in hydrophilic gels. Thus, the performance of drugs in gel formulations are influenced by their rheological properties [20].

It has been postulated that drug release from gel formulations varies directly with the square root of time [23]. Therefore, the membrane used has no significant effect on the release of the drug [24]. In this study HF was entirely dissolved in the gel. The inverse relation between viscosity and drug release has been demonstrated in several investigations regarding hydrophobic gelling agents $[21,22]$. In the present study, the kinetics of diffusion and the spatial dispersion of $\mathrm{HF}$ in the human ureter revealed that the chosen gel (gel c) could serve as an effective support for delivery of HF to urethra stenosis. This result has a significant advantage for the patients. In fact, systemic side effects of HF crossing blood stream should be minimized. A phase I study on orally administered HF showed severe complications for patients at doses 0.5 to 3.5 $\mathrm{mg} /$ day [25].

The absence of HF at the receptor compartment level in this study is a very encouraging result. Indeed, during the transition to phase I study, the risk of systemic passage of HF should be very low or even zero.

\section{CONCLUSION}

This study has successfully developed a new model mimicking the human urethra for predicting the diffusion of HF through three gels having different viscosities. The findings of this study show that hydrogel c with viscosity of 8851 cPs gave the best kinetics of diffusion of $\mathrm{HF}$ through the wall of the ureter in the delivery of $0.03 \%(\mathrm{w} / \mathrm{v})$ of the drug. The study also show the uniform distribution of HF following a tridimensional diffusion study using the new ex vivo model developed in this work. Thus, HF gels prepared using $\mathrm{NaCMC}$ as vehicle is a promising therapy for preventing the recurrence of urethral stenosis.

\section{DECLARATIONS}

\section{Acknowledgement}

The authors thank Urology Department of the $\mathrm{CHU}$ of Sousse.

\section{Conflict of Interest}

No conflict of interest associated with this work. 


\section{Contribution of Authors}

The authors declare that this work was done by the authors named in this article and all liabilities pertaining to claims relating to the content of this article will be borne by them.

\section{REFERENCES}

1. Morgia G, Saita A, Falsaperla M, Spampinato A, Motta M, Cordaro S. Immunohistochemical and molecular analysis in recurrent urethral stricture. Urol Res 2000; 28: 319-322.

2. Baskin LS, Constantinescu SC, Howard PS, McAninch JW, Ewalt DH, Duckett JW, Snyder HM, Macarak EJ. Biochemical characterization and quantitation of the collagenous components of urethral stricture tissue. $J$ Urol 1993; 150: 642-647.

3. Mundy AR, Andrich DE. Urethral strictures. BJU Int 2011; 107: 6-26.

4. Robine E, Rigaud J, Luyckx F, Le Clerc QC, Madec FX, Bouchot $O$, Branchereau J. Analyse des taux de succès des urétroplasties pour sténoses de l'urètre bulbaire chez l'homme adulte : revue systématique de la littérature. Prog Urol. 2017; 27: 49-57.

5. Granot I, Halevy O, Hurwitz S, Pines M. Halofuginone: an inhibitor of collagen type I synthesis. Biochim Biophys Acta 1993; 1156: 107-112.

6. Ozcelik MF, Pekmezci S, Saribeyoglu K, Unal E, Gumustas K, Dogusoy G. The effect of halofuginone, a specific inhibitor of collagen type 1 synthesis, in the prevention of esophageal strictures related to caustic injury. Am J Surg 2004; 187: 257-260.

7. Xavier S, Piek E, Fujii M, Javelaud D, Mauviel $A$, Flanders KC, Samuni AM, Felici A, Reiss M, Yarkoni S. Amelioration of radiation-induced fibrosis: inhibition of transforming growth factor-beta signaling by halofuginone. J Biol Chem 2004; 279: 15167-15176.

8. Pines M, Snyder D, Yarkoni S, Nagler A. Halofuginone to treat fibrosis in chronic graft-versus-host disease and scleroderma. Biology of blood and marrow transplantation: Biol Blood Marrow Transplant 2003; 9: 417-425.

9. Zeplin PH. Reduction of burn scar formation by halofuginone-eluting silicone gel sheets: a controlled study on nude mice. Ann Plast Surg 2012; 68: 271-275.

10. Spira G, Mawasi N, Paizi M, Anbinder N, Genina O, Alexiev $R$, Pines M. Halofuginone, a collagen type I inhibitor improves liver regeneration in cirrhotic rats. $J$ Hepatol 2002; 37: 331-339.

11. Nagler A, Rivkind Al, Raphael J, Levi-Schaffer F, Genina $O$, Lavelin I, Pines $M$. Halofuginonean inhibitor of collagen type I synthesis--prevents postoperative formation of abdominal adhesions. Ann Surg 1998; 227: 575-582.

12. Arbell $D$, Udassin R, Koplewitz BZ, Ohana M, Genina $O$, Pines M, Nagler A. Prevention of esophageal strictures in a caustic burn model using halofuginone, an inhibitor of collagen type I synthesis. Laryngoscope2005; 115: 1632-1635.

13. Jaidane M, Ali-El-Dein B, Ounaies A, Hafez AT, Mohsen $T$, Bazeed $M$. The use of halofuginone in limiting urethral stricture formation and recurrence: an experimental study in rabbits. J Urol 2003; 170: 20492052.

14. Rao KM, Mallikarjuna B, Rao KK, Prabhakar M, Rao KC, Subha M. Preparation and characterization of $\mathrm{pH}$ sensitive poly (vinyl alcohol)/sodium carboxymethyl cellulose IPN microspheres for in vitro release studies of an anti-cancer drug. Polymer Bulletin 2012; 68: 19051919.

15. Organization WH, Sciences CfIOoM. International ethical guidelines for health-related research involving humans: Geneva: Council for International Organizations of Medical Sciences; 2016

16. Sassi A, Hassairi A, Kallel M, Jaidane M, Saguem $S$. HPLC Method for Quantification of Halofuginone in Human Ureter: Ex-Vivo Application. J Chromatogr Sep Tech 2015; 6: 1.

17. Shirazi M, Khezri A, Samani SM, Monabbati A, Kojoori J, Hassanpour A. Effect of intraurethral captopril gel on the recurrence of urethral stricture after direct vision internal urethrotomy: Phase II clinical trial. Int J Urol 2007; 14: 203-208.

18. Krane LS, Gorbachinsky I, Sirintrapun J, Yoo JJ, Atala A, Hodges SJ. Halofuginone-coated urethral catheters prevent periurethral spongiofibrosis in a rat model of urethral injury. J Endourol2011; 25: 107-112.

19. Swamy BY, Yun YS. In vitro release of metformin from iron (III) cross-linked alginate-carboxymethyl cellulose hydrogel beads. Int J Biol Macromol 2015; 77: 114-119.

20. Ueda CT, Shah VP, Derdzinski K, Ewing G, Flynn G, Maibach $H$, Marques $M$, Rytting $H$, Shaw S, Thakker K, . Topical and transdermal drug products. 2009.

21. Nishida K, Nakakoga Y, Sato N, Kawakami S, Mukai T, Sasaki H, Sakaeda T, Nakamura J. . Effect of viscous additives on drug absorption from the liver surface in rats using phenol red as a model. Eur $J$ Pharm Biopharm 2000; 50: 397-402.

22. Ghosal K, Chandra A, Rajabalaya R, Chakraborty S, Nanda A. Mathematical modeling of drug release profiles for modified hydrophobic HPMC based gels. Pharmazie. 2012; 67: 147-155.

23. Higuchi WI. Analysis of data on the medicament release from ointments. J Pharm Sci 1962; 51: 802-80 4.

24. Guy RH, Hadgraft J. On the determination of drug release rates from topical dosage forms. Int $J$ Pharm 1990; 60: R1-R3.

25. De Jonge MJ, Dumez H, Verweij J, Yarkoni S, Snyder D, Lacombe D, Marréaud S, Yamaguchi T, Punt CJ, van Oosterom A . Phase I and pharmacokinetic study of halofuginone, an oral quinazolinone derivative in patients with advanced solid tumours. Eur $J$ Cancer 2006; 42: 1768-17674.

Trop J Pharm Res, May 2018; 17(5): 760 